This work is licensed under a Creative Commons Attribution 4.0 International License.

Ovaj rad dostupan je za upotrebu pod međunarodnom licencom Creative Commons Attribution 4.0.

https://doi.org/10.31820/f.31.1.8

Ana Šimić

\title{
NON-VERBAL CLAUSES WITH DEMONSTRATIVE IDENTIFIERS IN THE HISTORY OF CROATIAN
}

Ana Šimić, PhD, Old Church Slavonic Institute, ana.simic@stin.hr, Zagreb

izvorni znanstveni članak

UDK 811.163.42'367

811.163.42(091)

rukopis primljen: 18. veljače 2019.; prihvaćen za objavljivanje: 31. svibnja 2019.

The paper presents a corpus-based typological and diachronic study of nonverbal clauses with demonstrative identifiers in Croatian. As one of the four types of demonstratives proposed by $H$. Diessel, demonstrative identifiers occur in copular and non-verbal clauses. They are used to focus the hearer's attention on entities in the surrounding situation or in the universe of discourse.

The paper reviews the typologies of demonstratives discussed in recent literature with respect to the status of demonstrative identifiers. Furthermore, it investigates the history of non-verbal clauses with demonstrative identifiers in Croatian:
1. se človêkb
2. evo čovjeka
DEM man-NOM.SG
DEM man-GEN.SG
'Here is the man!'
'Here is the man!'

The main change occurred in the case marking on the argument. In the first Croatian literary language, Croatian Church Slavonic (1), the argument appears in the nominative case. In contemporary Croatian (2), the demonstrative identifier is predominantly followed by a genitive argument. Apart from shedding some light on the diachronic development of non-verbal clauses with demonstrative identifiers and their constituents in Croatian, the paper shows how they differ from similar constructions in other Slavic languages, as well as in some major European languages. In addition, they are 
compared to other non-verbal constructions with genitive and nominative arguments in Croatian.

Key words: demonstratives; demonstrative identifiers; non-verbal clauses; Croatian; diachronic syntax

\section{Demonstratives}

Demonstratives are deictic expressions that serve the purpose of orienting the hearer in the surrounding situation (cf. Diessel 1999: 2) and as such they are language universals (Dixon 2003: 61). What is almost universal is their specific semantic feature of deictic contrast, i.e. the indication of "the relative distance of a referent in the speech situation visà-vis the deictic centre" (Diessel 2013). According to Diessel (2013), it is very rare for a language to have distance-neutral demonstratives (only 7 out of 234 languages included in his research, which makes up 2\%). The majority of the world's languages, 127 out of 234 (54\%), express a two-way deictic contrast, while 88 (38\%) express a three-way contrast. Croatian is one such language, having e.g. adverbial demonstratives ovdje 'here', tu 'there', ondje 'over there'.

In linguistics, demonstratives are often discussed in the context of grammaticalization. ${ }^{1}$ Actually, they seem to "represent ideal candidates for the grammaticalization process" (Brala-Vukanović 2015: 48). The development of the definite article from demonstrative pronouns in Indo-European languages (cf. Catasso 2011) is perhaps one of the best-known cases of grammaticalization of demonstratives.

\subsection{Typologies of demonstratives with regard to demonstrative identifiers}

Diessel (1999: 57) formally distinguishes four types of demonstratives with respect to their specific syntactic context: (i) pronominal demonstratives, which independently substitute a noun or a noun-phrase, (ii) adnominal demonstratives, which accompany a co-occurring noun or a noun phrase, (iii) adverbial demonstratives, which function as verb modifiers, and (iv) identificational demonstratives, which are used in copular and non-verbal clauses to focus the hearer's attention on entities in

1 Grammaticalization is a process in which a lexical item develops grammatical functions. 
the surrounding situation or in the universe of discourse. These four types belong to different grammatical categories. Diessel refers to them as (i) demonstrative pronouns, (ii) demonstrative determiners, (iii) demonstrative adverbs, and (iv) demonstrative identifiers.

Dixon (2003) offers a different view of the cross-linguistic typology of demonstratives. According to him, there are three types of demonstratives: nominal, (local) adverbial and verbal demonstratives (Dixon 2003: 62). Nominal demonstratives actually unite Diessel's pronominal and adnominal demonstratives. As for adverbial demonstratives, Dixon (2003: 69-72) refers to them in terms of their function of conveying spatial and manner meaning. ${ }^{2} \mathrm{He}$ also introduces a new class of demonstratives, verbal demonstratives, which are very rare (recognised in Boumaa Fijian and Dyirbal). ${ }^{3}$ Finally, Dixon does not find it necessary to acknowledge demonstrative identifiers as a class of their own, although he acknowledges identification as a possible demonstrative function in some languages having a special demonstrative for identification (Dixon 2003: 84-85).

But this was somehow already anticipated by Diessel (1999: 79) himself when he noted that the demonstratives in identificational copular and non-verbal clauses are mostly considered to be demonstrative pronouns. However, Diessel (1999: 79) explains that if demonstratives in copular and non-verbal clauses are phonologically and morphologically distinguished from pronominal demonstratives in other clause types, then they truly do form a class of their own. This is the case in Ambulas (a Ndu language spoken in Papua New Guinea). Conversely, if demonstratives in copular and non-verbal clauses have the same phonological and morphological features as pronominal demonstratives in other contexts, they are not considered a separate class. English is an example of the latter.

Lastly, Lionett (2012) accepts Dixon's typology, excluding the 'do-likethis' verbs from Dixon's class of verbal demonstratives. In Lionett (2013: 32), however, an updated typology is proposed, which may be described as a combination of Diessel's and Dixon's typology, with five types of demonstratives (pronominal, adnominal, adverbial, verbal and identifica-

2 If we consider Croatian temporal demonstrative adverbs sada 'now', tada 'then' and onda 'back then', then Dixon's observation about some nominal and local adverbial demonstratives having a secondary temporal sense is quite interesting. "In just a few languages there are separate temporal forms", he adds (Dixon 2003: 62).

3 E.g., "The Boumaa Fijian verb 'ene(ii) can be glossed as "do like this"” (Dixon 2003: 72). 
tional demonstratives). To date, this seems to be the most comprehensive typology of demonstratives.

\section{Demonstratives in Croatian}

Throughout the history of Croatian, there have been four classes of demonstratives, the same ones that $\mathrm{H}$. Diessel mentioned: pronominal demonstratives/demonstrative pronouns (1a), adnominal demonstratives/ demonstrative determiners (1b), adverbial demonstratives/demonstrative adverbs (spatial adverbs, temporal adverbs, quantificational adverbs and adverbs of manner) (1c), and identificational demonstratives/demonstrative identifiers. There are no verbal demonstratives in the Croatian language.

The following examples are from the first Croatian literary language, Croatian Church Slavonic:

(1) a. g'rubo estb namb one imenovati ili s'lišati ove - II. Novi breviary, $15^{\text {th }}$ c., 393d (RCJHR)

'It is inappropriate for us to name those or listen to these.'

b. na ovu ubo or(a)c(iju) za židove r'ci p(o)m(o)l(imb) se Missal Illirico 4, $14^{\text {th }}$ c., 93d (RCJHR)

'In this prayer for the Jews say let us pray.'

c. ondê dubb preveliki stoêše dêmunomb pokr'ĉens - II. Novi breviary, $15^{\text {th }}$ c., $478 \mathrm{c}$ (RCJHR)

'Over there was a huge oak possessed by a demon.'

\section{Demonstrative identifiers in Croatian Church Slavonic}

\subsection{Demonstrative identifiers in copular clauses}

Demonstrative identifiers in the Croatian Church Slavonic language are attested in copular and non-verbal clauses. The examples of the former are:

(2) a. se e(stb) mihaelb $\operatorname{arh}(a) n \hat{\jmath}(e) l_{b}-I$. Beram breviary,

$$
15^{\text {th }} \text { c., } 151 b \text { (RCJHR) }
$$

'This is Archangel Michael.'

b. se sutb imena s(ve)tihb $m(u) \check{c}(e) n(i) k b$ - II. Novi breviary, $15^{\text {th }}$ c., $410 \mathrm{c}$ (RCJHR)

'These are the holy martyrs' names.' 
(3) to e $d(a) v(i) d$ ' i to su $n(e) b(e)$ skoga erusolima vrata -

Oxford miscellany, $15^{\text {th }}$ c., 4c (RCJHR)

'That is David and those are the Holy Jerusalem's gates.'

(4) a. ovo e(stb) ona mariê mag'dalena ${ }^{4}$ - Žgombić miscellany, $16^{\text {th }}$ c., 106v (RCJHR)

'This is the Mary from Magdala.'

b. ovo su grisi tvoi - Oxford miscellany, $15^{\text {th }}$ c., 3c (RCJHR)

'These are your sins.'

Both (2a) and (2b) have the same demonstrative identifier - se 'this'. But there is a difference in the inflectional categories of the coreferential NPs: mihaelb $\operatorname{arh}(a) n \hat{\jmath}(e) l_{b}$ is of masculine gender and appears in the nominative singular form, while imena is neuter and in the nominative plural form. Consequently, number agreement is also different (singular $e$ (stb) vs. plural sutb). Likewise, in (3) there is a single demonstrative identifier to 'that' for two coreferential NPs with different gender and number inflection. The same goes for examples with the demonstrative identifier ovo 'this' in (4a) and (4b).

Regarding se, to and ovo as demonstrative identifiers, it is important to add that in Croatian Church Slavonic there were corresponding demonstrative pronouns inflected for gender, number and case (Table 1). ${ }^{5}$

Table 1: Demonstrative pronouns: sa-se - si 'this'; ta - to - ta 'that'; ov - ovo - ova 'this'

\begin{tabular}{|c|c|c|c|}
\hline & $\mathrm{M}$ & $\mathrm{N}$ & $\mathrm{F}$ \\
\hline NOM.SG & $\begin{array}{l}s a, s i \\
t a \\
o v\end{array}$ & $\left(\begin{array}{l}\text { se, sjie } \\
\text { to } \\
\text { ovo }\end{array}\right)$ & $\begin{array}{l}\text { si, sija } \\
\text { ta } \\
\text { ova }\end{array}$ \\
\hline NOM.PL & $\begin{array}{l}\text { si } \\
\text { ti } \\
\text { ovi }\end{array}$ & $\begin{array}{l}\text { Sija } \\
\text { ta } \\
\text { ova }\end{array}$ & $\begin{array}{l}\text { sije, seje } \\
\text { te, ti } \\
\text { ove, ovi }\end{array}$ \\
\hline NOM.DU & $\begin{array}{l}\text { sija } \\
\text { ta } \\
\text { ova }\end{array}$ & $\begin{array}{l}s i \\
\text { tě } \\
\text { ově }\end{array}$ & \\
\hline
\end{tabular}

4 There is not only a demonstrative identifier ovo 'this' in this clause, but also a demonstrative determiner ona 'that one'.

5 Cf. Mihaljević (2014: 138, 148). 
Demonstrative identifiers se, to and ovo have the same phonological form as the nominative (accusative) singular neuter form of the corresponding demonstrative pronouns. Based on examples such as these (from German) Diessel (1999: 88) makes a case for distinguishing demonstrative identifiers from nominal demonstratives.

As previously stated, English does not have demonstrative identifiers because demonstratives in copular and non-verbal identificational clauses are not phonologically or morphologically different from nominal demonstratives in other contexts. On the other hand, Croatian demonstratives are different. Although demonstrative identifiers se and to have the same phonological form as the nominative (accusative) singular neuter form of the corresponding demonstrative pronouns, unlike pronouns, they are uninflected and, therefore, cannot agree with a coreferential noun. This is the morphological difference between demonstrative pronouns and demonstrative identifiers in Croatian. Examples (5a) and (5b) show that demonstrative pronouns agree with the head noun in gender, number and case:

(5) a. ? $\underline{s a}$ mihaelb $\operatorname{arh}(a) n \hat{\jmath}(e) l_{b}{ }^{6}$

this-NOM.SG Michael-NOM.SG archangel-NOM.SG

'This Archangel Michael.'

b. 'sija imena s(ve)tihb $m(u) \check{c}(e) n(i) k b$

this-NOM.PL name-NOM.PL saint-GEN.PL martyr-GEN.PL

'These names of holy martyrs.'

This grammatical difference makes it easier to understand why demonstrative identifiers should be acknowledged as a category of their own.

\subsection{Demonstrative identifiers in non-verbal clauses}

Non-verbal clauses appear to be a more suitable syntactic context to prove that demonstrative identifiers are a distinct category:

(6) a. (iskahomb dobra i) se smuĉenie - Breviary of Vid Omišljanin, $14^{\text {th }}$ c., 432 c (RCJHR)

DEM disorder-NOM.SG

'(We looked for the good and) here is disorder.'

6 The symbol ? means that these examples are not confirmed in the given corpus (RCJHR) but are grammatically correct.

7 Croatian demonstrative identifiers do not correspond to just one equivalent in English. Consequently, they will be translated differently throughout the paper. 
b. se az' rabag(ospod)na - Oxford miscellany, $15^{\text {th }}$ c., 29b (RCJHR)

DEM I-NOM.SG handmaid-NOM.SG Lord's-NOM.SG

'Behold I the handmaid of the Lord!'

In both examples, taken again from Croatian Church Slavonic, the demonstrative identifier se is followed by a noun (phrase) in the nominative case. Demonstrative identifiers in non-verbal clauses are identified as demonstrative particles in Croatian Church Slavonic (Kovačević 2014: 300). Such identification (as particles) stems from the traditional notion of grammatical word classes, and it is not uncommon. ${ }^{8}$

The differences between the previously introduced copular constructions and the non-verbal ones are formal, semantic and pragmatic in nature. The formal difference is obvious: there is no copula, i.e. there is no verb. The difference in semantics is highlighted by the English translation. Although there is one and the same demonstrative identifier in (2) and (6), and a noun phrase in the nominative case, the translation is different. Lastly, regarding pragmatics, copular clauses with demonstrative identifiers are, in essence, declarative, while the non-verbal ones are exclamative. They usually reflect the emotional or wilful engagement on the part of the speaker. This is why, for example, the latter kind of construction is absent from official documents and legal texts. In other words, non-verbal clauses with demonstrative identifiers are mostly used in spoken communication and, consequently, in direct speech. ${ }^{9}$ In addition, unlike copular clauses with demonstrative identifiers, which are mostly used to introduce someone or something, i.e. to identify someone/something, non-verbal constructions are usually used when someone or something that is already known to the participants in a conversation is presented in a new context. This is the reason why they are sometimes quite noticeably referred to as presentative particles or presentatives (e.g. Kordić 1997, Brala Vukanović 2015: 51, Kouwenberg 2012).

8 In grammars of contemporary Croatian, they are primarily referred to as particles (Silić, Pranjković 2005: 257; Raguž 2010: 270) but also as interjections (Barić et al. 1997: 437). For earlier identification and description of demonstrative identifiers in Croatian see Kordić 1997: 183-186.

9 Cf. Kordić 1997: 188. 
In the Croatian Glagolitic texts from the RCJHR corpus, se is the only demonstrative identifier that occurs in non-verbal clauses. ${ }^{10}$

\section{Demonstrative identifiers in non-verbal clauses in the later history of Croatian}

4.1. Outside the Croatian Church Slavonic corpus, ovo is also attested in non-verbal clauses:

(7) a. ovo raj gizdavi - Š. Menčetić, $16^{\text {th }}$ c. (Rječnik 1924-1927: 495)

DEM heaven-NOM.SG adorned-NOM.SG

'Behold the adorned heaven!'

b. ovo veselja neizmjernoga! - A. Gučetić, $16^{\text {th }} \mathrm{c}$.

(Rječnik 1924-1927: 495)

DEM joy-GEN.SG unmeasurable-GEN.SG

'Here is unmeasurable joy!'

Both (7a) and (7b) represent the same construction: a demonstrative identifier and a noun phrase. There is no copula and no verb. However, there is a difference in the case marking on the noun phrase. In (7b) it is no longer in the nominative case, as in (7a), but in the genitive. According to Rječnik 1924-1927: 495 , both possibilities coexisted during the $15^{\text {th }}-17^{\text {th }}$ century.

Sporadically, the demonstrative identifier ono is also attested in a similar construction:

(8) (...) ono i Pometa. - M. Držić, 16 ${ }^{\text {th }}$ c. (Rječnik 1924-1927: 6)

DEM and Pomet-GEN.SG

'There is Pomet, too.'

Comparable with the identifier ovo, ono is phonologically identical to the nominative/accusative singular neuter form of the corresponding demonstrative pronoun. Unlike se and nu (4.2.), ovo and ono are distancemarked. They express a two-way deictic contrast.

\footnotetext{
10 The demonstrative identifier se with a nominative argument in non-verbal clauses can be traced back to Old Church Slavonic. Večerka (1996: 148) identifies it as a deictic interjection (Ger. deiktische Interjection), cf. Slovník 1997: 49. However, sporadically, ese can be used in similar contexts (Slovník 1968: 583, Večerka 1996: 148) but it is not attested in Croatian Church Slavonic.
} 
4.2. The demonstrative identifier $n u$ appears in non-verbal constructions from the $18^{\text {th }}$ century onwards (Rječnik 1917-1922), with a noun phrase in the genitive case:

(9) a. Nu moje nesriće, (u što sam ja padnuo!) - Jerolim Filipović, $18^{\text {th }}$ c. (Rječnik 1917-1992: 258)

DEM my-GEN.SG calamity-GEN.SG

'Look at the calamity (I've fallen into)!'

b. A nu vojske! - V. Kaleb, 1973 (HJR)

but DEM army-GEN.SG

'But behold the army!'

c. nu logike - $(\mathrm{hr} . \mathrm{WaC})^{11}$

DEM logic-GEN.SG

'Oh, the logic!'

The demonstrative $n u$ is used in contemporary Croatian (9c), but not as often as evo, eto and eno (4.3.). There are no known examples of $n u$ as a demonstrative identifier in copular clauses.

4.3. Unlike se and $n u$, and similar to ovo and ono, demonstrative identifiers evo, eto and eno are distance-marked. In other words, they locate the referent at three different points on a distance scale: the proximal demonstrative identifier evo refers to an entity near the speaker, the medial demonstrative identifier eto refers to an entity near the hearer, while the distal demonstrative identifier eno refers to an entity away from both the speaker and the hearer. In addition, evo, eto, eno are not phonologically identical to any forms of demonstrative pronouns the way se, ovo and ono are. In a non-verbal clause they precede the noun phrase, which may be in the nominative (10a) or in the genitive case (10b):

(10) a. Evo kral vaš. - N. Ranjina, $16^{\text {th }}$ c. (Rječnik 1887-1891)

DEM king-NOM.SG your-NOM.SG

'Here is your king!'

$11 \mathrm{hrWaC}$ is a contemporary Croatian web corpus. The date is therefore omitted for hrWaC examples. 
b. Eto drače u jasleh. - A. Gučetić, $16^{\text {th }}$ c. (Rječnik 1887-1891)

DEM thorn-bush-GEN.SG in manger-LOC.PL

'There is thorn-bush in the manger!'

Both possibilities, i.e. nominative and genitive arguments, were attested at approximately the same period, and they co-exist even today. ${ }^{12}$ Also, in this paper both are considered to be subject(-like) arguments. ${ }^{13}$

According to Žic Fuchs 1991: 98, the majority of examples in contemporary Croatian are those with the genitive case. Moreover, it is interesting that speakers of Croatian consider the nominative in these constructions to be sub-standard.

Žic Fuchs' notion about the prevalence of genitive arguments is confirmed on a sample of examples from the hrWaC corpus. Genitive constituents appear in $81,80 \%$ of non-verbal clauses with demonstrative identifiers evo, eto and eno. ${ }^{14}$

Sporadically, in the history of Croatian the demonstrative identifier evo is attested in a copular clause:

(11) Evo ti je sinak! - Anonymous writer, $18^{\text {th }}$ c. (Rječnik 1887-1891: 37)

DEM you-DAT.SG be-3.SG son-NOM.SG

'Here is your son!'

In Rječnik 1887-1891: 37, the meaning attributed to evo in (11) is 'here'.

12 However, there are some constraints in contemporary Croatian. As noted by Kordić 1997: 187, unlike nouns, personal pronouns may appear only in the genitive case: Evo nas ${ }_{\mathrm{GEN} . \mathrm{PL}}$ ! and *Evo $m i_{\mathrm{NOM} . \mathrm{PL}}$ ! 'Here is us!'.

13 Barić et al. 1997: 437 mention an "object in the genitive" with "interjections" evo, eto and eno.

14 The analysis of hrWaC turned out 32,141 sentences with evo, eto and eno accompanied by a noun phrase (with a noun, adjective, pronoun or a numeral as the first word) in nominative and genitive. A sample of 1000 sentences was extracted and annotated manually. Of this number, 555 examples contained 566 non-verbal clauses with a demonstrative identifier. (The rest were mainly sentences in which demonstratives were syntactically independent, i.e. not embedded in a non-verbal clause. Also, some automatic annotations were incorrect, and some examples were excluded from the sample because of case syncretism, e.g. evo riječi, where riječi can be annotated as G.SG., N.PL. or G.PL). In the sample of 566 non-verbal clauses with demonstrative identifiers evo, eto and eno, there were 463 genitive arguments and 103 nominative arguments. 
There are no copular clauses with demonstrative identifiers evo, eto and eno in contemporary Croatian. For that purpose, other demonstrative identifiers are employed:

(12) Ovo sam ja u avataru. - forum.hr (hrWac) 'This is me in avatar form.'

In (12) the demonstrative identifiers to and ono may also be used. All three of them (proximal ovo, medial to and distal ono) are phonologically identical to the nominative/accusative singular neuter form of the corresponding demonstrative pronouns. ${ }^{15}$

\section{Other non-verbal constructions with genitive and nominative arguments in Croatian}

5.1. There is yet another kind of exclamative items, namely interjections, that may also appear in non-verbal constructions similar to those with demonstrative identifiers. In Croatian, starting from the Church Slavonic period (Kovačević 2013: 70; Kovačević 2014: 292), lamentation interjections co-occur with an argument in the genitive:

(13) a. vapiite $\underline{a} \underline{a} \underline{a} d(b) n e-B r e v i a r y ~ I l l y r i c o ~ 6,14^{\text {th }}$ c., 210c (Joel : 15)

(Kovačević 2013: 70: Kovačević 2014: 292)

cry out woe woe woe day-GEN.SG

'Cry unto the Lord: Alas for the day!' (BW8)

b. (...) ali jao viteške nevolje - E. Kumičić, $19^{\text {th }} \mathrm{c}$. (HJR)

but woe knight's-GEN.SG trouble-GEN.SG

'But woe the knight's trouble!'

The meaning of these constructions remains the same even if the argument appears in the nominative case:

(14) a. gore gore gradb veliki ... - Breviary of Vid Omišljanin, $14^{\text {th }} \mathrm{c}$.

(Rev. 18:16) 278a (Kovačević 2013: 65)

woe woe city-NOM.SG great-NOM.SG

'Alas, alas, that great city!' (BW8)

15 In hrWaC there are examples like Evo sam ovo planirao 'Here, I planned this.', but these are neither copular nor identificational. Copular clauses appear rarely (e.g. Evo sam opet $u$ Dnevniku 'Here, I'm in the news again') but they are not identificational. A deeper analysis of evo/eto/eno in these examples is yet to be conducted. 
b. Ajme koja tekma. - veleuciliste.hr (hrWac)

woah which-GEN.SG game-GEN.SG

'Whoa, what a game!'

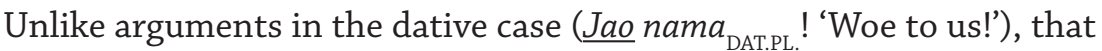
refer to someone who suffers because of a dreadful situation, both genitive and nominative arguments refer to the dreadful (surprising, astonishing) situation itself. In other words, genitive and nominative arguments are subject arguments in the exemplified constructions, while the dative ones are object arguments. ${ }^{16}$

5.2. There are other interjections in the Croatian language that may appear in non-verbal clauses with an argument in the genitive (cf. Kovačević 2013: 65-66) and - in the accusative:

(15) a. Ala lipa govoreńa! - N. Palikuća, $18^{\text {th }}$ c. (Rječnik 1880-1882: 60)

wow nice-GEN.SG talk-GEN.SG

'Wow, nice talk!'

b. (...) asti gušta - forum.hr (hrWaC) wow pleasure-GEN.SG

'Wow, what a pleasure!'

c. gle čuda - vecernji.hr ( $\mathrm{hrWaC})$

lo miracle-GEN.SG

'Lo, the miracle' (often ironical)

d. Gle nju, babu znatiželjnu - 24.sata.hr (hrWaC)

lo she-ACC.SG gammer-ACC.SG curious-ACC.SG

'Look at her, the nosy old biddy.'

Although the interjections in 5.1. and 5.2. are not canonical examples of demonstrative items, in the non-verbal constructions described they do have some kind of pointing and focusing function. Moreover, gle (15c and $15 \mathrm{~d}$ ) is considered to be a demonstrative (presentative) in contemporary Croatian (Silić, Pranjković 2005: 257), although its verbal origin (gledati 'to watch') is evident in the object argument in the accusative (15d).

16 Večerka (1996: 151-153) describes similar Old Church Slavonic non-verbal clauses with interjections $o$, ole, $o$ vele with a nominative, genitive and dative argument. 


\section{The case of John 19:5}

We have chosen a recognizable identificational exclamation phrase from the Gospel of John 19:27 (Latin Ecce homo!) to illustrate how Croatian non-verbal clauses with demonstrative identifiers may differ from similar constructions in some other Slavic and major European languages:

(16) CROATIAN: Evo čovjeka! (BW8)

SLOVENIAN: Poglejte, to je človek! (Bible)

SERBIAN: Ево човека! (BG)

MACEDONIAN: Еве Го човекот! (BW8)

BULGARIAN: Ето човекът! (BG)

RUSSIAN: Вот этот человек! (BW8)

UKRANIAN: Оче Чоловік! (BW8)

POLISH: Oto Człowiek. (BW8)

CZECH: Aj, člověk. (WP)

SLOVAK: Hla, človek! (BW8)

GERMAN: Da ist der Mensch! (BW8)

ENGLISH: Behold the man! (BW8)

SPANISH: He aquí el hombre! (BST)

ITALIAN: Ecco l'uomo! (BST)

All Slavic versions, except Slovenian, have similar non-verbal clauses. In Slovenian, there are two clauses: one with the imperative poglejte ('to see') and a copular one with the demonstrative to. As for the case marking of the argument, Croatian and Serbian have the genitive case. In Macedonian the pronoun go is in the accusative and therefore an object argument. In Bulgarian there is only the definiteness feature on the noun, while in all the other cited Slavic languages the argument is in the nominative case. Finally, when it comes to the first constituent in the nonverbal clause, it seems that Czech aj and Slovak hl'a are primarily interjections, not demonstratives.

Other, non-Slavic languages that we cited are the main representatives of Germanic and Romance languages. The German version of the anthological New Testament quote is a copular clause with the demonstrative adverb $d a$ ('there'). Following the interjection he, there is a demonstrative adverb in Spanish, too - aqui ('here', 'now'). German and Spanish 
spatial adverbs in the given example confirm that demonstratives are primarily used as spatial deictics (cf. Diessel 1999: 36). The English example is a verbal clause with an object. The Spanish and Italian versions both contain non-verbal clauses. If he and ecco are used with pronouns (heme aqui; eccomi 'here I am'), then object pronouns are used, not the subject ones (*heyo aqui; *eccoino). The Italian ecco may be comparable with the Latin ecce, which in Diessel 1999: 79 is not considered to be a demonstrative identifier, but a sentential demonstrative.

\section{Conclusion}

Table 2 summarizes the results of the diachronic analysis of demonstrative identifiers in the history of Croatian:

Table 2: Demonstrative identifiers in the history of Croatian

\begin{tabular}{|l|c|c|c|c|c|c|}
\hline $\begin{array}{c}\text { Demonstra- } \\
\text { tive } \\
\text { identifier }\end{array}$ & $\begin{array}{c}\text { Phonologically } \\
\text { identical to a } \\
\text { demonstrative } \\
\text { pronoun form }\end{array}$ & $\begin{array}{c}\text { Distance- } \\
\text { marked }\end{array}$ & $\begin{array}{c}\text { In } \\
\text { copular } \\
\text { clauses }\end{array}$ & $\begin{array}{c}\text { In } \\
\text { non- } \\
\text { verbal } \\
\text { clauses }\end{array}$ & $\begin{array}{c}\text { In non-verbal } \\
\text { clauses with } \\
\text { nominative } \\
\text { argument }\end{array}$ & $\begin{array}{c}\text { In non-verbal } \\
\text { clauses with } \\
\text { genitive } \\
\text { argument }\end{array}$ \\
\hline se & + & - & + & + & + & - \\
\hline ovo / ono & + & + & + & + & + & + \\
\hline nu & - & - & - & + & - & + \\
\hline $\begin{array}{l}\text { evo / eto / } \\
\text { eno }\end{array}$ & - & + & - & + & + & + \\
\hline
\end{tabular}

The analysis has also shown that apart from subject-like arguments in the nominative and genitive, object-like arguments in the accusative are also possible with some items that are considered to be demonstratives (gle). In addition, the study has shown that Croatian has non-verbal clauses with interjections/particles and a genitive/accusative argument that have a pointing/focusing function similar to that of demonstrative constructions. Last of all, the cross-Slavic comparison has highlighted the fact that the majority of Slavic languages have nominative arguments in non-verbal clauses with demonstrative function. 


\section{Sources}

BG - BibleGateway (https://www.biblegateway.com)

Bible - https://www.bible.com/hr

BST - Bible Study Tools (https://www.biblestudytools.com)

BW8 - BibleWorks 8

HJR - Hrvatska jezična riznica (http://riznica.ihjj.hr/index.hr.html)

hrWaC - Croatian web corpus (http://nlp.ffzg.hr/resources/corpora/hrwac/)

RCJHR - paper-card corpus of the Dictionary of the Croatian redaction of Church Slavonic, available at the Old Church Slavonic institute in Zagreb

RJEČNIK - Rječnik hrvatskoga ili srpskoga jezika, 1880. - 1975., Zagreb, Jugoslavenska akademija znanosti i umjetnosti.

WP - WordProject (https://www.wordproject.org)

\section{References}

Barić, Eugenija, Mijo Lončarić, Dragica Malić, Slavko Pavešić, Mirko Peti, Vesna Zečević, Marija Znika (1997) Hrvatska gramatika, Školska knjiga, Zagreb.

Brala Vukanović, Maja (2015) "Communication and grammaticalization. The case of (Croatian) demonstratives", Fluminensia, 27, 2, 45-60.

Catasso, Nicholas (2011) "The grammaticalization of demonstratives: a comparative analysis", Journal of Universal Language, 12, 7-46.

Diessel, Holger (1999) Demonstratives: form, function and grammaticalization, John Benjamins Publishing Company, Amsterdam, Philadelphia.

Diessel, Holger (2013) "Distance Contrasts in Demonstratives", The World Atlas of Language Structures Online, Matthew S. Dryer and Haspelmath, Martin, Leipzig, http://wals.info/chapter/41, accessed on 2019-01-01.

Dixon, Robert M. W. (2003) "Demonstratives. A cross-linguistic typology", Studies in Language 27, 61-122.

Kordić, Snježana (1997), "Prezentativi evo, eto, eno", Slavia 66/2, 183-196.

Kovačević, Ana (2013), "Gore vamb knižnici: rekcija uzvika u hrvatskoglagoljskim tekstovima”, Slovo 63: 55-81. 
Kovačević, Ana (2014) “Uzvici”, Hrvatski crkvenoslavenski jezik, prir. Milan Mihaljević, Zagreb, 287-293.

Kovačević, Ana (2014) “Čestice”, Hrvatski crkvenoslavenski jezik, prir. Milan Mihaljević, Zagreb, 295-301.

Kouwenberg, Nobertus J. C. (2012), „Spatial Deixis in Akkadian: Demonstrative Pronouns, Presentative Particles and Locational Adverbs", Zeitschrift für Assyriologie und vorderasiatische Archäologie, Volume 102, Issue 1, 17-75.

Lionnet, Florian (2012) Unusual grammar leads to unusual grammaticalization: verbal demonstratives in the Juu languages. M.A. qualification paper, UC Berkeley, http://www.princeton.edu/ flionnet/papers/Lionnet_ MApaper.pdf, 8 September 2018.

Lionnet, Florian (2013) “The Typology of demonstratives clarified: Verbal demonstratives in Ju/'hoan (slides, pdf)", Paper presented at the 10th Biennial Conference of the Association for Linguistic Typology (ALT 10), University of Leipzig, Leipzig.

http://www.princeton.edu/ flionnet/papers/Lionnet_ALT10Leipzig2013.pdf, 8 September 2018.

Mihaljević, Milan (2014) “Zamjenice”, Hrvatski crkvenoslavenski jezik, prir. Milan Mihaljević, Zagreb, 133-150.

Raguž, Ivica (2010) Gramatika hrvatskoga jezika, Vlastita naklada, Zagreb.

Silić, Josip, Pranjković, Ivo (2005) Gramatika hrvatskoga jezika za gimnazije i visoka učilišta, Zagreb, Školska knjiga.

Slovník 1968. Slovník jazyka staroslovenskeho I/2: vęzati - j. Academia, Praha.

Slovník 1997. Slovník jazyka staroslovenskeho IV: s - î. Academia, Praha.

Večerka, Radoslav (1996) Altkirchenslavische (Altbulgarische) Syntax III. Die Satztypen: der einfache Satz, Freiburg i. Br., Weiher.

Žic Fuchs, Milena (1991), "On contrasting expressions of spatial deixis in Croatian and English", Studia Romanica et Anglica Zagrabiensia 36-37, 93-102. 


\section{SAŽETAK}

Ana Šimić

\section{POVIJEST BEZGLAGOLSKIH REČENICA S DEMONSTRATIVNIM IDENTIFIKATORIMA U HRVATSKOM JEZIKU}

U članku je predstavljena korpusna, tipološka i dijakronijska raščlamba bezglagolskih rečenica s demonstrativnim identifikatorima (prezentativima) u povijesti hrvatskoga jezika. Kao jednom od četiri tipa demonstrativa, prema H. Diesselu, sintaktički je kontekst demonstrativnih identifikatora kopularna ili bezglagolska rečenica. Funkcija im je usmjeriti sugovornikovu pozornost na pojedinosti izvanjezične ili unutarjezične stvarnosti. U članku su predstavljene najnovije tipologije demonstrativa s osvrtom na status demonstrativih identifikatora. Nadalje, korpusnom su i povijesnom raščlambom predstavljene bezglagolske rečenice s demonstrativnim identifikatorima u hrvatskom jeziku:

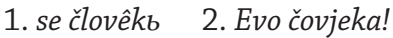

Najveća promjena odnosi se na padež imenskoga argumenta. U prvom hrvatskom književnom jeziku, hrvatskom crkvenoslavenskom imenska je riječ u nominativu (1), dok je u suvremenom hrvatskom jeziku ona najčešće u genitivu (2).

Osim povijesne raščlambe zadanih bezglagolskih rečenica, u članku je provedena usporedba sa sličnim bezglagolskim konstrukcijama u čijem su sastavu uzvici ili čestice $i$ imenski argument u nominativu, genitivu i akuzativu. Konačno, hrvatske bezglagolske rečenice s demonstrativnim identifikatorima uspoređene su sa sličnim komstrukcijama u nekim slavenskim i drugim jezicima Europe.

Ključne riječi: demonstrativi; demonstrativni identifikatori; prezentativi; bezglagolske rečenice; hrvatski jezik; povijesna sintaksa 